\title{
Host Diagnostic Biomarkers of Infection in the ICU: Where Are We and Where Are We Going?
}

\author{
Aaron J. Heffernan ${ }^{1,2}$ (D) $\cdot$ Kerina J. Denny ${ }^{3,4}$ (D) \\ Accepted: 27 January 2021 / Published online: 12 February 2021 \\ (C) Crown 2021
}

\begin{abstract}
Purpose of Review Early identification of infection in the critically ill patient and initiation of appropriate treatment is key to reducing morbidity and mortality. On the other hand, the indiscriminate use of antimicrobials leads to harms, many of which may be exaggerated in the critically ill population. The current method of diagnosing infection in the intensive care unit relies heavily on clinical gestalt; however, this approach is plagued by biases. Therefore, a reliable, independent biomarker holds promise in the accurate determination of infection. We discuss currently used host biomarkers used in the intensive care unit and review new and emerging approaches to biomarker discovery.

Recent Findings White cell count (including total white cell count, left shift, and the neutrophil-leucocyte ratio), C-reactive protein, and procalcitonin are the most common host diagnostic biomarkers for sepsis used in current clinical practice. However, their utility in the initial diagnosis of infection, and their role in the subsequent decision to commence treatment, remains limited. Novel approaches to biomarker discovery that are currently being investigated include combination biomarkers, host 'sepsis signatures' based on differential gene expression, site-specific biomarkers, biomechanical assays, and incorporation of new and pre-existing host biomarkers into machine learning algorithms.

Summary To date, no single reliable independent biomarker of infection exists. Whilst new approaches to biomarker discovery hold promise, their clinical utility may be limited if previous mistakes that have afflicted sepsis biomarker research continue to be repeated.
\end{abstract}

Keywords Infection $\cdot$ Sepsis $\cdot$ Biomarkers $\cdot$ ICU $\cdot$ Clinical gestalt

\section{Introduction}

The early and accurate identification of infection in a critically ill patient, either as a cause of their critical illness or as a complication of it, is key to reducing infection-associated morbidity and mortality from delayed treatment [1].

This article is part of the Topical Collection on Sepsis and ICU

Kerina J. Denny

k.denny@uq.edu.au

1 School of Medicine, Griffith University, Gold Coast, QLD, Australia

2 Centre for Translational Anti-infective Pharmacodynamics, Faculty of Medicine, University of Queensland, Herston, QLD, Australia

3 Department of Intensive Care, Gold Coast University Hospital, Gold Coast, QLD, Australia

4 School of Clinical Medicine, Faculty of Medicine, University of Queensland, Herston, QLD, Australia
Critical illness of almost any aetiology, however, can mimic infection. Classic signs of infection (e.g. pyrexia, tachycardia) are common and non-specific amongst patients in the intensive care unit (ICU) $[2,3]$. It is therefore tempting to adopt a 'just in case' mindset to the treatment of infection in the ICU to avoid missing a curable infectious disease. This approach involves the widespread, relatively indiscriminate administration of broad-spectrum antimicrobials to critically ill patients.

However, unnecessary antimicrobial use lead to harms, including adverse drug events, risk of secondary opportunistic infections, and antimicrobial resistance $[2,4]$. Such harms are likely to be particularly pronounced in the critically ill population, partly due to the underlying critical illness that increases susceptibility to organ injury.

A biological marker (biomarker) is defined as 'a characteristic that is objectively measured and evaluated as an indicator of a normal biological process, pathogenic processes, or pharmacological responses to therapeutic interventions' [5]. 
Biomarkers have been touted as a solution to the clinical dilemma of differentiating infection from non-infectious mimics [6]. Diagnostic biomarkers of infection can be broadly divided into two groups: (i) those that identify microbes and (ii) those that identify the host response to microbes. Point-of-care tests that aim to identify the presence of microbes are being developed, but these assays are susceptible to false positives due to the identification of microorganisms that are not responsible for patient deterioration (i.e. from contamination or colonisation) [2].

Herein, we discuss current approaches to the diagnosis of infection in the ICU, with an emphasis on commonly used biomarkers of the host response to infection. We also discuss emerging approaches to biomarker development and examine how we can improve the quality of sepsis biomarker research with the aim of improving outcomes for critically ill patients with infection.

\section{Current Methods of Diagnosing Sepsis}

\section{Clinical Gestalt}

In the absence of a reliable independent biomarker of infection, clinicians rely heavily on clinical gestalt, which is informed by adjunctive laboratory tests of the host response to infection including white cell count (WCC), C-reactive protein (CRP) and/or procalcitonin (PCT), and microbiological cultures. Clinical gestalt describes the concept that clinicians actively organise clinical perceptions into a coherent construct with the aim of answering a clinical question. It involves making a decision in the absence of complete information based on pattern recognition.

Clinicians rarely rely on a single clinical sign (e.g. fever) or a biomarker result to decide whether a patient has an infection. Rather, they make an 'educated guess' that a patient likely has an infection based on their history, examination, and available laboratory, microbiology, and/or radiology results without applying any specific evidence-based clinical decision rules. Such an approach affords flexibility and the inclusion of factors that may be difficult to quantify [7] but may be inaccurate depending on the experience and ability of the clinician [8].

The inaccuracy of clinical gestalt in the diagnosis of sepsis in ICU patients has been demonstrated in multiple studies [9-11]. In a recent multicentre clinical cohort examined by Lopansri and colleagues [10], agreement between initial attending physician diagnosis of sepsis in ICU patients compared to retrospective diagnosis by an expert panel was weak (free-marginal kappa agreement 0.58 ). The tendency was to overdiagnose sepsis early, with $\sim 30 \%$ of those initially determined to be septic being subsequently reclassified retrospectively. Overtreatment was also observed, with $\sim 60 \%$ of patients ultimately classified as having a non-infectious systemic inflammatory response syndrome (SIRS) being given systemic antimicrobials.

One reason that clinical gestalt may perform so poorly when it comes to the diagnosis of infection in critically ill patients is that it is susceptible to multiple cognitive biases, including base-rate neglect, outcome, and premature closure (Table 1). Given the potential for poor outcomes with delayed antimicrobial initiation [1], clinicians may focus on the perceived benefit of antimicrobial administration even if the presentation may not be consistent with an infectious diagnosis - an example of base-rate neglect [12]. Clinicians tend to therefore overestimate the true prevalence of infection [10, 13•, 14].

Base-rate neglect is intertwined with outcome bias in that clinicians may inappropriately attribute a patient's clinical improvement to antimicrobial administration as part of a presumed infection diagnosis, even in cases where infection is unlikely [12]. Clinicians may also rely on the perceived safety of antimicrobials in ascribing a patient's presentation to infection, despite evidence demonstrating significant harms from unnecessary antimicrobial therapy [2]. Finally, healthcare institutional pressures may bias clinicians towards a diagnosis of infection. For example, a study by Kanwar and colleagues [17] identified an increase in community acquired pneumonia diagnosis rates when a 4 - $\mathrm{h}$ antimicrobial administration rule was implemented in the emergency department (ED).

To avoid such clinical biases, a clinician may put increased weight on biomarkers of infection, which may be perceived as potentially more objective. Some of the more commonly used in current clinical practice are discussed in detail below.

\section{White Cell Count}

The WCC has long been considered an important and readily available clinical marker of infection. However, the utility of this commonly used haematological parameter in the diagnosis of infection in critically ill patients is questionable.

In a retrospective review of 2279 patients admitted to a tertiary hospital with suspected infection, an abnormal WCC $\left(\geq 12 \times 10^{9} / \mathrm{L}\right.$ or $\left.\leq 4 \times 10^{9} / \mathrm{L}\right)$ was demonstrated to have a sensitivity, specificity, positive predictive value, and negative predictive value of $52.5 \%, 52.8 \%, 63.3 \%$, and $41.7 \%$, respectively [18]. The poor diagnostic utility of the total WCC in ICU patients is a consistent finding [19]. This is unsurprising given the wide variety of non-infectious mimics, drugs, and comorbidities that influence the total WCC [20-24]. Further, the total WCC may decrease acutely due to sequestration of granulocytes at the site of infection, with a delay in the release of neutrophils from the bone marrow [25]. Therefore, the clinician may see a different WCC picture depending on the time the sample was taken relative to symptom onset.

To improve the diagnostic yield of WCC in diagnosing infection, other methods of interrogating the WCC have been 
Table 1 Examples of biases applied to the diagnosis of infection $[15,16]$

\begin{tabular}{|c|c|c|}
\hline Bias & Description & Example \\
\hline Availability bias & $\begin{array}{l}\text { The tendency for something to be judged more frequent if it readily } \\
\text { comes to mind }\end{array}$ & $\begin{array}{l}\text { Sepsis is commonly encountered, and awareness and } \\
\text { education campaigns are ubiquitous. Infection is therefore } \\
\text { frequently entertained as a differential diagnosis, and this } \\
\text { may contribute to overdiagnosis and overtreatment }\end{array}$ \\
\hline $\begin{array}{l}\text { Anchoring and } \\
\text { adjustment }\end{array}$ & $\begin{array}{l}\text { Anchoring describes the tendency to fixate on specific features of a } \\
\text { presentation too early in the diagnostic process. This fixation } \\
\text { prevents the clinician from adjusting their diagnosis following } \\
\text { potentially disconfirming information }\end{array}$ & $\begin{array}{l}\text { A patient with a fever is judged to have an infection and } \\
\text { antimicrobials are commenced. An occlusive deep vein } \\
\text { thrombosis is subsequently found which could account for } \\
\text { the fever in the context of negative microbiological } \\
\text { cultures. Nonetheless, antimicrobials are continued }\end{array}$ \\
\hline $\begin{array}{l}\text { Attribution, } \\
\text { impact and } \\
\text { affect bias }\end{array}$ & $\begin{array}{l}\text { Attribution bias is a focus on positive outcomes attributed to a specific } \\
\text { intervention increasing a clinician's confidence and feelings of } \\
\text { attachment (affect bias) to the effect of the intervention whilst } \\
\text { minimising the harms of the intervention (impact bias) }\end{array}$ & $\begin{array}{l}\text { A clinician focuses on the perceived favourable patient } \\
\text { outcomes following antimicrobial therapy, potentially } \\
\text { neglecting the negative adverse effects of antimicrobials } \\
\text { (e.g. diarrhoea) }\end{array}$ \\
\hline $\begin{array}{l}\text { Base-rate neglect } \\
\text { and framing } \\
\text { effect }\end{array}$ & $\begin{array}{l}\text { An inaccurate (over or under) estimation of the true prevalence of } \\
\text { disease. This may be altered by the framing effect whereby a } \\
\text { diagnosis and subsequent actions may be unduly influenced by the } \\
\text { probability of the diagnosis }\end{array}$ & $\begin{array}{l}\text { Over-estimating the risk of infection may lead clinicians to } \\
\text { prescribe unnecessary antimicrobials }\end{array}$ \\
\hline $\begin{array}{l}\text { Commission } \\
\text { bias }\end{array}$ & A tendency towards action rather than inaction & $\begin{array}{l}\text { Antimicrobials are given in preference to a 'watch and wait' } \\
\text { approach as it is considered 'safer' practice }\end{array}$ \\
\hline $\begin{array}{l}\text { Confirmation } \\
\text { bias }\end{array}$ & $\begin{array}{l}\text { The tendency to look for confirming evidence to support the } \\
\text { hypothesis rather than look for refuting evidence. This is } \\
\text { exacerbated by search satisfying (see below) }\end{array}$ & $\begin{array}{l}\text { Suspecting a pneumonia in a patient based on a fever and } \\
\text { ignoring other clinical and laboratory evidence that does } \\
\text { not support infection (e.g. lack of a radiological findings } \\
\text { consistent with pneumonia) }\end{array}$ \\
\hline $\begin{array}{l}\text { Search satisfying } \\
\text { (premature } \\
\text { closure) }\end{array}$ & $\begin{array}{l}\text { Ceasing to look for further information or alternative answers when } \\
\text { the first plausible solution is found. }\end{array}$ & $\begin{array}{l}\text { A patient with an increasing oxygen requirement and a fever } \\
\text { is diagnosed as having a ventilator associated pneumonia. } \\
\text { The clinician does not investigate for other causes of } \\
\text { respiratory deterioration (e.g. pulmonary embolism) }\end{array}$ \\
\hline
\end{tabular}

explored, including assessment of immature granulocytes and, more recently, the neutrophil-lymphocyte ratio (NLR).

Immature granulocytes ('bands') are released from bone marrow following cytokine stimulation. The presence of bands is described as a 'left shift' and has been associated with infection (OR 8.91, 95\% CI 3.46-22.93) [19] and with a sensitivity and specificity of $84 \%$ and $71 \%$, respectively, when an $8.5 \%$ cut-off is used [26]. In separate studies, increasing the cut-off to $19-25 \%$ improved the specificity to approximately $86 \%$ with a corresponding reduction in the sensitivity by up to $25 \%$ [27]. The presence of toxic neutrophil features, such as toxic granules and cytoplasmic vacuoles, was the most sensitive blood film feature with a sensitivity of $88 \%[27,28]$.

Another potentially discerning feature of the WCC and differential is the NLR. During periods of physiological stress and in response to bacterial infections, the neutrophil count typically increases with a reduction in the lymphocyte population, potentially due to cortisol release $[29,30]$. In one study of 1572 patients in the ED with suspected sepsis, the NLR modestly predicted bacteraemia (AUROC $0.71,95 \%$ CI $0.67-$ 0.75), which was not statistically different from PCT [31]. Moreover, the NLR modestly predicted microbiologically confirmed infection (AUROC 0.63, 95\% CI 0.61-0.66) [31]. Similar results have been observed in other cohorts [32, 33].
The utility of the NLR decreases with viral infection [34]. Overall, the NLR has improved sensitivity but reduced specificity when compared with other commonly used biomarkers (CRP and PCT) for diagnosing bacterial sepsis [31, 32].

Taken together, the total value of the WCC is a poorly performing diagnostic test of infection. Other measures, such as the NLR and band count may be an improvement on the total WCC but still lack both the sensitivity and specificity to discern inflammation from infection in critically ill patients.

\section{C-Reactive Protein}

CRP is an acute phase reactant synthesised and released from the liver in response to infection and inflammation [35]. Numerous studies have been performed detailing the diagnostic accuracy of CRP for infection.

A meta-analysis of 12 studies investigating the diagnosis of bacterial infections in immunocompetent patients primarily with sepsis identified a CRP sensitivity and specificity of 0.75 (95\% CI 0.62-0.84) and 0.67 (95\% CI 0.56-0.77), respectively, a finding which has been replicated in ICU cohorts [36, 37]. Conversely, CRP was not able to differentiate patients with and without microbiologically proven infection meeting Sepsis-3 criteria with a CRP AUROC of only 0.57 
(95\% CI 0.54-0.60) [31, 38•]. Results between studies may vary due to different cut-off values used. Overall, the optimal cut-offs identified generally range between 20 and $100 \mathrm{mg} / \mathrm{L}$, with lower and higher CRP concentrations improving sensitivity and specificity, respectively $[31,36,37,39,40]$. This should also be considered when utilising the CRP to differentiate between bacterial and viral infections. CRP has a sensitivity range of 0.61 to 1 and specificity of 0.26 to 1 depending on the cut-off CRP value used in the study to differentiate bacterial from viral infections [36, 41]. Optimal sensitivity and specificity cut-off values are approximately $40 \mathrm{mg} / \mathrm{L}$ and $>80 \mathrm{mg} / \mathrm{L}$, respectively, in distinguishing bacterial from viral infections [36, 41-43]. No difference in CRP has been shown between patients with and without SARS-CoV-2 (COVID-19); however, the CRP 95\% CI ranges from 24.7 to $31.4 \mathrm{mg} / \mathrm{L}$ suggesting that high $\mathrm{CRP}$ concentrations may imply an alternative diagnosis $[44,45]$.

A commonly touted reason for the variability in the diagnostic utility of CRP between studies is patient heterogeneity. However, no appreciable difference exists in the CRP AUROC, sensitivity, or specificity for diagnosing infection in patients with febrile neutropenia compared with the previously described immunocompetent patients [40]. This is similar to other immunocompromised populations (chronic liver disease patients, transplant patients, human immunodeficiency virus [HIV] patients, and haematopoietic stem cell transplant recipients) and patients with hepatic dysfunction, with the potential exception of fulminant hepatic failure $[39,46 \bullet$, 47, 48]. Therefore, CRP may assist clinicians where the WCC and differential may be less useful, such as those with febrile neutropenia.

One method to improve the diagnostic utility of CRP may be to repeat the test at different time points. Patients presenting early in the illness course may have an increased risk of initial false negative results resulting in delayed treatment initiation that may be associated with a mortality of $19.4 \%$ [35, 49]. Daily CRP monitoring in ICU patients with an increase of $>41 \mathrm{mg} / \mathrm{L}$ from the previous day predicted bacterial infection with a sensitivity and specificity of 0.92 and 0.71 , respectively, with similar results improving the diagnosis of bacterial versus viral infections [50, 51].

Taken together, CRP has modest diagnostic potential in differentiating infectious from non-infectious inflammation; however, a 'normal' initial CRP does not exclude the potential for severe bacterial infection and should not be used to withhold appropriate treatment.

\section{Procalcitonin}

PCT is one of the most widely studied sepsis diagnostic biomarkers in ICU $[52,53]$. PCT, the peptide precursor to calcitonin, is released from thyroid $\mathrm{C}$ glands at undetectable concentrations healthy individuals, but is synthesised in extra-thyroid tissues in response to infection and inflammation via interleukins and tumour necrosis factor- $\alpha[52,53]$.

Several systematic reviews and meta-analyses have been performed that describe the utility of PCT in distinguishing bacterial infections or sepsis from SIRS [36, 54-66, 67•, 68]. The overall sensitivity and specificity range from 0.72 to 0.93 and 0.64 to 0.84 , respectively $[36,54-66,67 \cdot, 68]$. The associated positive and negative likelihood ratio ranged 3 to 5.9 and 0.11 to 0.44 , respectively $[36,54-66,67 \cdot, 68]$. Taken together, results suggest that PCT has modest discriminatory ability of distinguishing bacterial infection or sepsis from noninfectious inflammation; however, a negative result cannot rule out infection.

Potential differences between study results may be related to specific patient populations and infections. A lower diagnostic AUROC (0.71) and sensitivity $(0.66,95 \%$ CI 0.54 0.76) was identified in immunocompromised patients with bacteraemia when compared with immunocompetent patients (sensitivity $0.76,95 \%$ CI $0.75-0.83$ ) [57]. Similarly, in patients with renal impairment (estimated glomerular filtration rate $<30 \mathrm{~mL} / \mathrm{min} / 1.73 \mathrm{~m}^{2}$ ), PCT poorly differentiated infectious from non-infectious inflammation, which may be related to potentially higher baseline PCT concentrations in this patient cohort, although results are mixed $[69,70]$. PCT had reduced sensitivity but increased specificity in differentiating bacterial infection from disease flare in patients with autoimmune conditions [71]. Conversely, there was no appreciable difference in the sensitivity, specificity, or AUROC in differentiating bacterial infection from non-infectious inflammation between medical and surgical/trauma patients, paediatric and adult patients, patients with hepatic dysfunction, and burns patients $[47,54,56,58,61,63]$.

Heterogeneity may also result from different infectious aetiologies. PCT has mixed results in the ability to differentiate bacterial from viral infections with sensitivity and specificity ranges of between 0.64 to 0.95 and 0.42 to 0.91 , respectively $[36,65,72 \bullet]$. More recently, no difference in PCT concentrations were identified between patients with and without COVID-19; however, the PCT concentration was low with the $95 \%$ CI ranging from only 0.07 to $0.12 \mathrm{ng} / \mathrm{mL}[44,45]$. Similar diagnostic results have been shown in distinguishing bacterial from fungal infections [66, 73]. PCT can differentiate extracellular bacterial pathogens from intracellular bacteria, such as those commonly causing atypical community acquired pneumonia (Legionella spp., Chlamydophila pneumoniae, Mycoplasma pneumoniae), where the latter atypical bacteria usually do not appreciably increase the PCT concentration [74•]. Similar findings have been observed in intracellular bacteraemia [75]. Overall, PCT cut-offs $<2 \mathrm{ng} / \mathrm{mL}$ improve diagnostic sensitivity and may improve early initiation of treatment [76]. However, even with this low cut-off, clinicians should exercise caution in patients presenting acutely who may yet to have a detectable increase in PCT given the delay 
to peak concentrations of up to 24-h, although no benefit of repeated measurements over a shorter time frame of 12 -h has been shown in ICU patients [77, 78]. Conversely, PCT concentrations $>2 \mathrm{ng} / \mathrm{mL}$ improve diagnostic specificity and may assist in confirming treatment requirement for extracellular bacterial infection.

PCT is a potentially useful biomarker in assisting clinicians in the diagnosis of bacterial infections but may be limited by variability in some patient subgroups and infectious aetiologies. The clinician should consider the probability of bacterial infection as a continuum of the PCT with an increased likelihood at higher PCT concentrations.

\section{Biomarkers for Antimicrobial Treatment Modification}

Antimicrobial de-escalation (reducing antimicrobial spectrum) and truncated treatment durations have been proposed as methods to reduce the ecological collateral impact of antimicrobial use without compromising (and potentially improving) patient outcomes [79], a therapeutic decision which may be guided by biomarkers.

Data are available for CRP and PCT demonstrating a role in guiding antimicrobial cessation. Two recent studies did not show any difference in clinical cure rates or clinically significant difference in antimicrobial treatment durations for critically ill patients receiving CRP-guided antimicrobial therapy, compared with either a fixed 7-day course or cliniciandirected treatment $[80,81]$. On the other hand, a PCT concentration $<1 \mathrm{ng} / \mathrm{mL}$ and/or a reduction from the peak concentration by $65-90 \%$ has been used to safely cease antimicrobial therapy. This method has been shown to reduce the duration of antimicrobials by $\sim 2$ days, without influencing length of stay or patient mortality [82-84]. However, the mean length of antimicrobial therapy in the PCT-guided, CRP-guided, and standard care treatment arms for most studies remains $>7$ days [82-84]. Emerging evidence suggests that antimicrobial durations as short as 5-7 days may be appropriate in many clinical circumstances, such as community-acquired pneumonia or intraabdominal infections with appropriate source control [85-89]. It is currently unclear whether CRP or PCT may individualise the patient's treatment duration by reducing the duration below that recommended for 'short-course' therapy or whether there is a role for existing biomarkers in other forms of antimicrobial de-escalation.

\section{Emerging Research into Diagnostic Biomarkers of Sepsis}

Hundreds of diagnostic sepsis biomarkers been reported in the literature [90]. In addition to the ones described above, other commonly purported diagnostic protein biomarkers include sTREM-1 [91, 92], suPAR [93], CD64 [94], presepsin [95, 96], pentraxin-3 [97], calprotectin [98], and IL-6 [99]. However, none of these biomarkers have yet to have proven obviously superior when compared with each other and currently used biomarkers such as PCT.

Given the biological complexity of sepsis, a strategy based on a panel of multiple biomarkers is likely to have more potential to meet the needs of an ideal diagnostic test than any single biomarker [2]. Thus, using combinations of previously identified biomarkers has been recently investigated to improve diagnosis accuracy [100-103]. For example, a recent meta-analysis concluded that the combined application of CRP and CD64 improved the accuracy of neonatal sepsis diagnosis [102]. Combining a panel of biomarkers together with clinical information may prove even more accurate [90, 104].

Others are investigating the host gene response to infection in order to develop a genetic 'sepsis signature' from differentially expressed genes. There are currently two commercial tests based on host gene expression under development, SeptiCyte LAB (Immunexpress Inc., Seattle WA, USA) [105] and HostDX Sepsis (Inflammatix, Burlingame CA, USA) [106]. The diagnostic accuracies of these tests have been recently independently validated using gene expression data prospectively collected in an ICU-based randomised control trial, revealing a AUROC of 0.8 using the HostDX Sepsis 'Sepsis MetaScore' and an AUROC of 0.68 for the SeptiCyte Lab SeptiScore [107]. Performance of these assays improves in less heterogeneous subpopulations $[107,108]$.

The use of site-specific biomarkers is an emerging research area that may assist clinicians to differentiate infection from either colonisation or aseptic inflammation. For example, pentraxin-3 in bronchoalveolar lavage samples has been shown to predict pneumonia in intubated patients [109]. Similarly, the use of cerebrospinal fluid analysis may also assist with central nervous system infections. Cerebrospinal fluid interleukin- $1 \beta$ was able to differentiate identify culturepositive results in patients with suspected ventriculitis and ventriculoperitoneal shunt infections [110]. Cerebrospinal fluid kynurenine [111] and faecal CXCL-5 messenger-RNA [112] also represent new potential site-specific biomarkers.

Alternative avenues of biomarker research include exploring the biomechanical properties of immune cells. For example, Crawford and colleagues have conceptualised an assay based on changes in granulocyte deformability in patients with sepsis compared controls [113]. Others have proposed measuring leucocyte adhesion [114]. However, these biomechanical assays remain in their infancy.

Finally, there has been increasing interest in machine learning techniques to improve diagnostic accuracy. Machine learning enables the incorporation and quantification of the effect of multiple non-linear variables, allowing for the 
identification of unfamiliar trends and the development of prediction models. A recent systematic review demonstrated that machine learning models can accurately predict sepsis onset with good discrimination in retrospective cohorts [115]. Combining machine learning algorithms using electronic medical record data together with previously identified biomarkers may further increase diagnostic accuracy [108, 116]. However, prospective studies are required to ensure the clinical relevance of machine learning techniques. Notably, machine learning techniques remain susceptible to many of the same limitations of other research approaches, especially in the absence of a gold standard diagnostic test and prospective validation [117•].

Sepsis biomarker discovery remains a very much active field with several new investigative approaches. However, in order to ensure effective translation to the bedside, several prerequisites need to be fulfilled. Some of the problems of, and solutions to, biomarker research are discussed below.

\section{Addressing Problems with Sepsis Biomarker Research}

Unfortunately, sepsis biomarker research is riddled with problems that have precluded the translation of many newly discovered biomarkers into routine clinical practice. Some of these problems have been recently described [90, 118].
The biomarker literature is littered with small studies $(<100$ patients) with a high risk of bias and an absence of large-scale, high-quality prospective randomised trials $[90,118]$.

Further, many studies use control groups that are extremely unlikely to have sepsis, which not only fails to reflect the 'real world' utility of sepsis biomarkers but also result in an overestimation of biomarker performance. In the worst examples, sepsis biomarkers are evaluated against healthy control nonhospitalised subjects. Like any laboratory-based biomarker (e.g. troponin, d-dimer), it is proposed that sepsis biomarkers are best used in cases where true clinical equipoise exists [119], that is, when the bedside clinician is unsure as to whether to prescribe an antimicrobial.

Hindering this approach has been the absence of a true gold standard for diagnosing sepsis, even retrospectively. Microbiological cultures are a commonly used gold standard but can be problematic due to contamination, colonisation, and the high prevalence of culture negative infection [2]. In ICU patients, $28-49 \%$ of patients with a syndrome consistent with likely sepsis have negative cultures $[1$, 120-123]. One proposed solution to this problem is to use a panel of independent clinicians to retrospectively diagnose sepsis using a combination of: clinical findings; laboratory, radiological, and microbiological culture results; and response to therapy. Ideally, the group of clinicians would include at least one clinical microbiologist.

Another commonly stated problem impeding sepsis biomarker research is the heterogeneity of the sepsis syndrome. The host immune response is likely to vary depending on the

Table 2 Problems encountered in sepsis diagnostic biomarker research

\begin{tabular}{|c|c|c|}
\hline Problem & Description & Potential solution \\
\hline $\begin{array}{l}\text { Lack of a gold } \\
\text { standard }\end{array}$ & $\begin{array}{l}\text { Many patients in the ICU have culture negative infections, making it } \\
\text { challenging to confidently distinguish infection from } \\
\text { non-infectious mimics, even retrospectively }\end{array}$ & $\begin{array}{l}\text { Specialist multi-disciplinary panels may improve the } \\
\text { identification of patients with likely infection, thereby } \\
\text { ensuring that patients with culture-negative infection are } \\
\text { appropriately included in analyses }\end{array}$ \\
\hline $\begin{array}{l}\text { Effect of } \\
\text { comorbidities } \\
\text { and treatments }\end{array}$ & $\begin{array}{l}\text { Different disease states (e.g. renal failure), specific patient factors } \\
\text { (e.g. age, current medications), and treatments (e.g. renal } \\
\text { replacement therapy) are likely to change the expected } \\
\text { concentration of the biomarker in both diseased and non-diseased } \\
\text { states }\end{array}$ & $\begin{array}{l}\text { Further studies of biomarkers are required in specific patient } \\
\text { populations to ensure: the biomarker reference range is } \\
\text { valid in that population, adjustment of the reference range, } \\
\text { or exclusion of the use of the biomarker in that subgroup }\end{array}$ \\
\hline $\begin{array}{l}\text { Disease } \\
\text { heterogeneity }\end{array}$ & $\begin{array}{l}\text { Sepsis is a heterogeneous syndrome with individual variations in the } \\
\text { host responses to infections. A single host biomarker is unlikely to } \\
\text { be diagnostic in all patients }\end{array}$ & $\begin{array}{l}\text { Host biomarkers of sepsis should be evaluated against } \\
\text { specific sepsis phenotypes }\end{array}$ \\
\hline $\begin{array}{l}\text { Small study } \\
\text { sample size }\end{array}$ & $\begin{array}{l}\text { Many biomarker diagnostic studies are small, limiting the potential } \\
\text { analysis of specific patient subgroups }\end{array}$ & $\begin{array}{l}\text { Biomarker studies need to be adequately powered and sample } \\
\text { size calculations routinely reported }\end{array}$ \\
\hline $\begin{array}{l}\text { Failure to } \\
\text { consider } \\
\text { pre-test } \\
\text { probability }\end{array}$ & $\begin{array}{l}\text { Sepsis biomarker research often aims to provide a specific cut-off } \\
\text { value providing a 'yes' or 'no' answer to whether a patient has an } \\
\text { infection without considering the pre-test likelihood of disease }\end{array}$ & $\begin{array}{l}\text { A Bayesian approach should be applied to sepsis biomarker } \\
\text { research, where a biomarker result is interrogated as a } \\
\text { continuous variable that is interpreted in the context of the } \\
\text { pre-test probability of infection }\end{array}$ \\
\hline $\begin{array}{l}\text { Inappropriate } \\
\text { control groups }\end{array}$ & $\begin{array}{l}\text { Sepsis biomarkers are often interrogated against populations which } \\
\text { are very unlikely to have sepsis, including healthy controls }\end{array}$ & $\begin{array}{l}\text { Prospective validation of sepsis biomarkers should occur in } \\
\text { populations where clinical equipoise exists at the time of } \\
\text { commencing antimicrobials }\end{array}$ \\
\hline
\end{tabular}


precise microbiological organ insult and host [124•]. A possible solution to this is testing sepsis biomarkers well-defined cohorts based on a specific disease (e.g. burns, community acquired pneumonia) or identified sepsis subphenotypes [124•].

A summary of common problems encountered in biomarker research and possible solutions are described in Table 2.

\section{Conclusions}

Given the above problems troubling sepsis biomarker research, it is not surprising that the vast majority of discovered host diagnostic biomarkers of sepsis have not found their way into routine ICU clinical practice. The biomarkers that currently influence antimicrobial decision-making for many clinicians, including WCC, CRP, and PCT, do not meet the prerequisite accuracy and validity to be utilised as an independent diagnostic test to guide the initiation of sepsis treatment.

Whilst we await the emergence of a valid, accurate pointof-care diagnostic test for sepsis, we would endorse an approach to current sepsis diagnostic biomarkers as described recently by Huang and Ramirez [119]. Namely, the clinician at the bedside should consider the pre-test probability for the diagnosis and consider whether confounding factors exist that could interfere with the interpretation of the result.

Novel approaches to sepsis diagnostic biomarker research, including the use of combination biomarker panels and/or incorporation of biomarkers into machine learning models, hold promise. We await further large-scale prospective studies assessing these techniques, with the ultimate aim of demonstrating improvements in patient-oriented outcomes in critically ill patients with sepsis.

Acknowledgements Aaron Heffernan would like to acknowledge funding from a Griffith School of Medicine Research Higher degree scholarship.

Author Contribution AJH and KJD wrote the draft manuscript and critically appraised the manuscript.

Availability of Data and Material Not applicable.

Code Availability Not applicable.

\section{Compliance with Ethical Standards}

Conflict of Interest Aaron Heffernan and Kerina Denny declare that they have no conflicts of interest.

Human and Animal Rights and Informed Consent This article does not contain any studies with human or animal subjects performed by any of the authors.

\section{References}

Papers of particular interest, published recently, have been highlighted as:

- Of importance

1. Kumar A, Roberts D, Wood KE, Light B, Parrillo JE, Sharma S, et al. Duration of hypotension before initiation of effective antimicrobial therapy is the critical determinant of survival in human septic shock. Crit Care Med. 2006;34:1589-96.

2. Denny KJ, De Waele J, Laupland KB, Harris PNA, Lipman J. When not to start antibiotics: avoiding antibiotic overuse in the intensive care unit. Clin Microbiol Infect. 2020;26:35-40

3. Niven DJ, Laupland KB. Pyrexia: aetiology in the ICU. Crit Care. 2016;20:247.

4. Denny KJ, Cotta MO, Parker SL, Roberts JA, Lipman J. The use and risks of antibiotics in critically ill patients. Expert Opin Drug Saf. 2016;15:667-78.

5. Biomarkers Definitions Working G. Biomarkers and surrogate endpoints: preferred definitions and conceptual framework. Clin Pharmacol Ther. 2001;69:89-95.

6. Opal SM, Wittebole X. Biomarkers of Infection and Sepsis. Crit Care Clin. 2020;36:11-22.

7. Filbin MR, Lynch J, Gillingham TD, Thorsen JE, Pasakarnis CL, Nepal S, et al. Presenting symptoms independently predict mortality in septic shock: importance of a previously unmeasured confounder. Crit Care Med. 2018;46:1592-9.

8. Kabrhel C, Camargo CA Jr, Goldhaber SZ. Clinical gestalt and the diagnosis of pulmonary embolism: does experience matter? Chest. 2005; 127:1627-30.

9. Rhee C, Kadri SS, Danner RL, Suffredini AF, Massaro AF, Kitch BT, et al. Diagnosing sepsis is subjective and highly variable: a survey of intensivists using case vignettes. Crit Care. 2016;20:89.

10. Lopansri BK, Miller Iii RR, Burke JP, Levy M, Opal S, Rothman $\mathrm{RE}$, et al. Physician agreement on the diagnosis of sepsis in the intensive care unit: estimation of concordance and analysis of underlying factors in a multicenter cohort. J Intensive Care. 2019;7:13. https://doi.org/10.1186/s40560-019-0368-2.

11. Stevens JP, Kachniarz B, Wright SB, Gillis J, Talmor D, Clardy P, et al. When policy gets it right: variability in US. Hospitals' diagnosis of ventilator-associated pneumonia. Crit Care Med. 2014;42:497-503.

12. Vick A, Estrada CA, Rodriguez JM. Clinical reasoning for the infectious disease specialist: a primer to recognize cognitive biases. Clin Infect Dis. 2013;57:573-8.

13. Hoops KEM, Fackler JC, King A, Colantuoni E, Milstone AM, Woods-Hill C. How good is our diagnostic intuition? Clinician prediction of bacteremia in critically ill children. BMC Med Inform Decis Mak. 2020;20:8. https://doi.org/10.1186/s12911020-01165-3. Highlights the low positive predictive value of clinician gestalt.

14. Klein Klouwenberg PM, Cremer OL, van Vught LA, Ong DS, Frencken JF, Schultz MJ, et al. Likelihood of infection in patients with presumed sepsis at the time of intensive care unit admission: a cohort study. Crit Care. 2015;19:319.

15. Keijzers G, Fatovich DM, Egerton-Warburton D, Cullen L, Scott IA, Glasziou P, et al. Deliberate clinical inertia: using metacognition to improve decision-making. Emerg Med Australas. 2018;30:585-90.

16. Scott IA, Soon J, Elshaug AG, Lindner R. Countering cognitive biases in minimising low value care. Med J Aust. 2017;206:40711.

17. Kanwar M, Brar N, Khatib R, Fakih MG. Misdiagnosis of community-acquired pneumonia and inappropriate utilization of 
antibiotics: side effects of the 4-h antibiotic administration rule. Chest. 2007;131:1865-9.

18. Lai NA, Kruger P. The predictive ability of a weighted systemic inflammatory response syndrome score for microbiologically confirmed infection in hospitalised patients with suspected sepsis. Crit Care Resusc. 2011;13:146-50.

19. Cavallazzi R, Bennin CL, Hirani A, Gilbert C. Marik PE. Is the band count useful in the diagnosis of infection? An accuracy study in critically ill patients. J Intensive Care Med. 2010;25:353-7.

20. Stefaniuk P, Szymczyk A, Podhorecka M. The neutrophil to lymphocyte and lymphocyte to monocyte ratios as new prognostic factors in hematological malignancies - a narrative review. Cancer Manag Res. 2020;12:2961-77.

21. Dolan RD, McMillan DC. The prevalence of cancer associated systemic inflammation: implications of prognostic studies using the Glasgow Prognostic Score. Crit Rev Oncol/Hematol. 2020;150:16. https://doi.org/10.1016/j.critrevonc.2020.102962.

22. Kong WH, He YY, Bao HR, Zhang WL, Wang XY. Diagnostic value of neutrophil-lymphocyte ratio for predicting the severity of acute pancreatitis: a meta-analysis. Dis Markers. 2020;9. https:// doi.org/10.1155/2020/9731854.

23. Pascual-González Y, López-Sánchez M, Dorca J, Santos S. Defining the role of neutrophil-to-lymphocyte ratio in COPD: a systematic literature review. Int J Chron Obstruct Pulmon Dis. 2018;13:3651-62.

24. Galliazzo S, Nigro O, Bertu L, Guasti L, Grandi AM, Ageno W, et al. Prognostic role of neutrophils to lymphocytes ratio in patients with acute pulmonary embolism: a systematic review and meta-analysis of the literature. Intern Emerg Med. 2018;13:603-8.

25. Honda T, Uehara T, Matsumoto G, Arai S, Sugano M. Neutrophil left shift and white blood cell count as markers of bacterial infection. Clin Chim Acta. 2016;457:46-53.

26. Mare TA, Treacher DF, Shankar-Hari M, Beale R, Lewis SM, Chambers DJ, et al. The diagnostic and prognostic significance of monitoring blood levels of immature neutrophils in patients with systemic inflammation. Crit Care. 2015;19:11. https://doi. org/10.1186/s13054-015-0778-z.

27. Seebach JD, Morant R, Rüegg R, Seifert B, Fehr J. The diagnostic value of the neutrophil left shift in predicting inflammatory and infectious disease. Am J Clin Pathol. 1997;107:582-91.

28. Ardron MJ, Westengard JC, Dutcher TF. Band neutrophil counts are unnecessary for the diagnosis of infection in patients with normal total leukocyte counts. Am J Clin Pathol. 1994;102:646-9.

29. Shoenfeld Y, Gurewich Y, Gallant LA, Pinkhas J. Prednisoneinduced leukocytosis. Influence of dosage, method and duration of administration on the degree of leukocytosis. Am J Med. 1981;71:773-8.

30. Onsrud M, Thorsby E. Influence of in vivo hydrocortisone on some human blood lymphocyte subpopulations. I. Effect on natural killer cell activity. Scand J Immunol. 1981;13:573-9.

31. Ljungstrom L, Pernestig AK, Jacobsson G, Andersson R, Usener B, Tilevik D. Diagnostic accuracy of procalcitonin, neutrophillymphocyte count ratio, C-reactive protein, and lactate in patients with suspected bacterial sepsis. PLoS One. 2017;20:e0181704. https://doi.org/10.1371/journal.pone.0181704.

32. Westerdijk K, Simons KS, Zegers M, Wever PC, Pickkers P, de Jager CPC. The value of the neutrophil-lymphocyte count ratio in the diagnosis of sepsis in patients admitted to the intensive care unit: a retrospective cohort study. PLoS One. 2019;27:e0212861. https://doi.org/10.1371/journal.pone.0212861.

33. de Jager CP, van Wijk PT, Mathoera RB, de Jongh-Leuvenink J, van der Poll T, Wever PC. Lymphocytopenia and neutrophillymphocyte count ratio predict bacteremia better than conventional infection markers in an emergency care unit. Crit Care. 2010;14: R192. https://doi.org/10.1186/cc9309.
34. Naess A, Nilssen SS, Mo R, Eide GE, Sjursen H. Role of neutrophil to lymphocyte and monocyte to lymphocyte ratios in the diagnosis of bacterial infection in patients with fever. Infection. 2017;45:299-307.

35. Vincent JL, Donadello K, Schmit X. Biomarkers in the critically ill patient: C-reactive protein. Crit Care Clin. 2011;27:241-51.

36. Simon L, Gauvin F, Amre DK, Saint-Louis P, Lacroix J. Serum procalcitonin and C-reactive protein levels as markers of bacterial infection: a systematic review and meta-analysis. Clin Infect Dis. 2004:39:206-17.

37. Povoa P, Coelho L, Almeida E, Fernandes A, Mealha R, Moreira $\mathrm{P}$, et al. C-reactive protein as a marker of infection in critically ill patients. Clin Microbiol Infect. 2005;11:101-8.

38• van Oers JAH, de Jong E, Kemperman H, Girbes ARJ, de Lange DW. Diagnostic accuracy of procalcitonin and c-reactive protein is insufficient to predict proven infection: a retrospective cohort study in critically ill patients fulfilling the Sepsis-3 criteria. J Appl Lab Med. 2020;5:62-72. Highlights the potential inaccuracy of commonly used biomarkers for infections.

39. Khedher S, Fouthaili N, Maoui A, Lahiani S, Salem M, Bouzid K. The diagnostic and prognostic values of $\mathrm{C}$-reactive protein and procalcitonin during bacterial infections in decompensated cirrhosis. Gastroenterol Res Pract. 2018;2018:7. https://doi.org/10.1155/ 2018/5915947.

40. Wu C-W, Wu J-Y, Chen C-K, Huang S-L, Hsu S-C, Lee MTG, et al. Does procalcitonin, C-reactive protein, or interleukin-6 test have a role in the diagnosis of severe infection in patients with febrile neutropenia? A systematic review and meta-analysis. Support Care Cancer. 2015;23:2863-72.

41. Kapasi AJ, Dittrich S, Gonzalez IJ, Rodwell TC. Host biomarkers for distinguishing bacterial from non-bacterial causes of acute febrile illness: a comprehensive review. PLoS One. 2016;11:29. https://doi.org/10.1371/journal.pone.0160278.

42. Haran JP, Beaudoin FL, Suner S, Lu S. C-reactive protein as predictor of bacterial infection among patients with an influenzalike illness. Am J Emerg Med. 2013;31:137-44.

43. Tamune H, Takeya H, Suzuki W, Tagashira Y, Kuki T, Honda H, et al. Cerebrospinal fluid/blood glucose ratio as an indicator for bacterial meningitis. Am J Emerg Med. 2014;32:263-6.

44. Soraya GV, Ulhaq ZS. Crucial laboratory parameters in COVID19 diagnosis and prognosis: an updated meta-analysis. Med Clin. 2020;155:143-51.

45. Elshazli RM, Toraih EA, Elgaml A, El-Mowafy M, El-Mesery M, Amin MN, et al. Diagnostic and prognostic value of hematological and immunological markers in COVID-19 infection: A metaanalysis of 6320 patients. PLoS One. 2020;15:20. https://doi.org/ 10.1371/journal.pone.0238160.

46• de Oliveira VM, Moraes RB, Stein AT, Wendland EM. Accuracy of $\mathrm{C}$-reactive protein as a bacterial infection marker in critically immunosuppressed patients: a systematic review and meta-analysis. J Crit Care. 2017;42:129-37. Systematic review highlighting the diagnostic accuracy of CRP in different immunosuppressed patients.

47. Bota DP, Van Nuffelen M, Zakariah AN, Vincent JL. Serum levels of C-reactive protein and procalcitonin in critically ill patients with cirrhosis of the liver. J Lab Clin Med. 2005;146:34751.

48. Silvestre JP, Coelho LM, Póvoa PM. Impact of fulminant hepatic failure in C-reactive protein? J Crit Care. 2010;25:657.e7-12.

49. Wasserman A, Karov R, Shenhar-Tsarfaty S, Paran Y, Zeltzer D, Shapira I, et al. Septic patients presenting with apparently normal C-reactive protein: a point of caution for the ER physician. Medicine (Baltimore). 2019;98:e13989. https://doi.org/10.1097/ MD.0000000000013989.

50. Póvoa P, Coelho L, Almeida E, Fernandes A, Mealha R, Moreira $\mathrm{P}$, et al. Early identification of intensive care unit-acquired 
infections with daily monitoring of C-reactive protein: a prospective observational study. Crit Care. 2006;10:R63. https://doi.org/ $10.1186 / \mathrm{cc} 4892$.

51. Coster D, Wasserman A, Fisher E, Rogowski O, Zeltser D, Shapira I, et al. Using the kinetics of C-reactive protein response to improve the differential diagnosis between acute bacterial and viral infections. Infection. 2020;48:241-8.

52. Gregoriano C, Heilmann E, Molitor A, Schuetz P. Role of procalcitonin use in the management of sepsis. J Thorac Dis. 2020;12:S5-S15.

53. Vijayan AL, Vanimaya, Ravindran S, Saikant R, Lakshmi S, Kartik R, et al. Procalcitonin: a promising diagnostic marker for sepsis and antibiotic therapy. J Intensive Care. 2017;5:7. https:// doi.org/10.1186/s40560-017-0246-8.

54. Wacker C, Prkno A, Brunkhorst FM, Schlattmann P. Procalcitonin as a diagnostic marker for sepsis: a systematic review and meta-analysis. Lancet Infect Dis. 2013;13:426-35.

55. Tang BMP, Eslick GD, Craig JC, McLean AS. Accuracy of procalcitonin for sepsis diagnosis in critically ill patients: systematic review and meta-analysis. Lancet Infect Dis. 2007;7:210-7.

56. Uzzan B, Cohen R, Nicolas P, Cucherat M, Perret GY. Procalcitonin as a diagnostic test for sepsis in critically ill adults and after surgery or trauma: a systematic review and meta-analysis. Crit Care Med. 2006;34:1996-2003.

57. Hoeboer SH, van der Geest PJ, Nieboer D, Groeneveld ABJ. The diagnostic accuracy of procalcitonin for bacteraemia: a systematic review and meta-analysis. Clin Microbiol Infect. 2015;21:474-81.

58. Mann EA, Wood GL, Wade CE. Use of procalcitonin for the detection of sepsis in the critically ill burn patient: a systematic review of the literature. Burns. 2011;37:549-58.

59. Liu Y, Hou JH, Li Q, Chen KJ, Wang SN, Wang JM. Biomarkers for diagnosis of sepsis in patients with systemic inflammatory response syndrome: a systematic review and meta-analysis. SpringerPlus. 2016;5:10. https://doi.org/10.1186/s40064-0163591-5.

60. Pfister R, Kochanek M, Leygeber T, Brun-Buisson C, Cuquemelle E, Machado MBP, et al. Procalcitonin for diagnosis of bacterial pneumonia in critically ill patients during 2009 H1N1 influenza pandemic: a prospective cohort study, systematic review and individual patient data meta-analysis. Crit Care. 2014;18:11. https://doi.org/10.1186/cc13760.

61. Cabral L, Afreixo V, Almeida L, Paiva JA. The use of procalcitonin (pct) for diagnosis of sepsis in burn patients: a meta-analysis. PLoS One. 2016;11:16. https://doi.org/10.1371/ journal.pone. 0168475 .

62. Wu CC, Lan HM, Han ST, Chaou CH, Yeh CF, Liu SH, et al. Comparison of diagnostic accuracy in sepsis between presepsin, procalcitonin, and C-reactive protein: a systematic review and meta-analysis. Ann Intensive Care. 2017;7:16. https://doi.org/10. 1186/s13613-017-0316-z.

63. Pontrelli G, De Crescenzo F, Buzzetti R, Jenkner A, Balduzzi S, Carducci FC, et al. Accuracy of serum procalcitonin for the diagnosis of sepsis in neonates and children with systemic inflammatory syndrome: a meta-analysis. BMC Infect Dis. 2017;17:12. https://doi.org/10.1186/s12879-017-2396-7.

64. Haeusler GM, Carlesse F, Phillips RS. An updated systematic review and meta-analysis of the predictive value of serum biomarkers in the assessment of fever during neutropenia in children with cancer. Pediatr Infect Dis J. 2013;32:E390-E6.

65. Wu MH, Lin CC, Huang SL, Shih HM, Wang CC, Lee CC, et al. Can procalcitonin tests aid in identifying bacterial infections associated with influenza pneumonia? A systematic review and metaanalysis. Influenza Other Respir Viruses. 2013;7:349-55.

66. Dou YH, Du JK, Liu HL, Shong XD. The role of procalcitonin in the identification of invasive fungal infection-a systemic review and meta-analysis. Diagn Microbiol Infect Dis. 2013;76:464-9.
67. • Kondo Y, Umemura Y, Hayashida K, Hara Y, Aihara M, Yamakawa K. Diagnostic value of procalcitonin and presepsin for sepsis in critically ill adult patients: a systematic review and meta-analysis. J Intensive Care. 2019;7:22. https://doi.org/10. 1186/s40560-019-0374-4. Systematic review comparing presepsis and procalcitonin for the diagnosis of sepsis in critically ill patients.

68. Tan MC, Lu YX, Jiang H, Zhang LD. The diagnostic accuracy of procalcitonin and $\mathrm{C}$-reactive protein for sepsis: a systematic review and meta-analysis. J Cell Biochem. 2019;120:5852-9.

69. El-Sayed D, Grotts J, Golgert WA, Sugar AM. Sensitivity and specificity of procalcitonin in predicting bacterial infections in patients with renal impairment. Open Forum Infect Dis. 2014;1: ofu068. https://doi.org/10.1093/ofid/ofu068.

70. Park JH, Kim DH, Jang HR, Kim MJ, Jung SH, Lee JE, et al. Clinical relevance of procalcitonin and C-reactive protein as infection markers in renal impairment: a cross-sectional study. Crit Care. 2014;18:640. https://doi.org/10.1186/s13054-014-0640-8.

71. Tamaki K, Kogata Y, Sugiyama D, Nakazawa T, Hatachi S, Kageyama G, et al. Diagnostic accuracy of serum procalcitonin concentrations for detecting systemic bacterial infection in patients with systemic autoimmune diseases. J Rheumatol. 2008;35:114-9.

72• Kamat IS, Ramachandran V, Eswaran H, Guffey D, Musher DM. Procalcitonin to distinguish viral from bacterial pneumonia: a systematic review and meta-analysis. Clin Infect Dis. 2020;70: 538-42. Meta-analysis comparing the use of procalcitonin for the diagnosis of viral vs. bacterial pneumonia. The diagnostic accuracy is insufficient to with-hold antibiotics in patients with presumed pneumonia.

73. Cortegiani A, Misseri G, Ippolito M, Bassetti M, Giarratano A, Martin-Loeches I, et al. Procalcitonin levels in candidemia versus bacteremia: a systematic review. Crit Care. 2019;23:190. https:// doi.org/10.1186/s13054-019-2481-y.

74•. Self WH, Balk RA, Grijalva CG, Williams DJ, Zhu Y, Anderson EJ, et al. Procalcitonin as a marker of etiology in adults hospitalized with community-acquired pneumonia. Clin Infect Dis. 2017;65:183-90. This paper further supports the findings of Kamat et al. but focusses on the use of procalcitonin concentration to inform a predicted probability of bacterial vs. viral infection.

75. Lin MF, Sun B, Liu ZY, Tang P, Zhang LJ, Wang YY. Evaluation of the clinical diagnostic value of traditional inflammatory markers and novel biomarkers in intracellular bacterial bloodstream infections. Cytokine. 2020;136:7. https://doi.org/10.1016/ j.cyto.2020.155238.

76. Goodlet KJ, Cameron EA, Nailor MD. Low sensitivity of procalcitonin for bacteremia at an academic medical center: a cautionary tale for antimicrobial stewardship. Open Forum Infect Dis. 2020;7:6. https://doi.org/10.1093/ofid/ofaa096.

77. Dandona P, Nix D, Wilson MF, Aljada A, Love J, Assicot M, et al. Procalcitonin increase after endotoxin injection in normal subjects. J Clin Endocrinol Metab. 1994;79:1605-8.

78. Levin PD, Cohen MJ, Ohev-Zion E, Tannus S, Stohl S, Avidan A, et al. The effect of repeated versus initial procalcitonin measurements on diagnosis of infection in the intensive care setting: a prospective observational study. Anesth Analg. 2019;129:E114 E7.

79. De Bus L, Depuydt P, Steen J, Dhaese S, De Smet K, Tabah A, et al. Antimicrobial de-escalation in the critically ill patient and assessment of clinical cure: the DIANA study. Intensive Care Med. 2020;46:1404-17.

80. Petel D, Winters N, Gore GC, Papenburg J, Beltempo M, Lacroix $\mathrm{J}$, et al. Use of C-reactive protein to tailor antibiotic use: a systematic review and meta-analysis. BMJ Open. 2018;8:e022133. https://doi.org/10.1136/bmjopen-2018-022133. 
81. Borges I, Carneiro R, Bergo R, Martins L, Colosimo E, Oliveira $\mathrm{C}$, et al. Duration of antibiotic therapy in critically ill patients: a randomized controlled trial of a clinical and C-reactive proteinbased protocol versus an evidence-based best practice strategy without biomarkers. Crit Care. 2020;24:281. https://doi.org/10. 1186/s13054-020-02946-y.

82. Iankova I, Thompson-Leduc P, Kirson NY, Rice B, Hey J, Krause A, et al. Efficacy and safety of procalcitonin guidance in patients with suspected or confirmed sepsis: a systematic review and metaanalysis. Crit Care Med. 2018;46:691-8.

83. Meier MA, Branche A, Neeser OL, Wirz Y, Haubitz S, Bouadma $\mathrm{L}$, et al. Procalcitonin-guided antibiotic treatment in patients with positive blood cultures: a patient-level meta-analysis of randomized trials. Clin Infect Dis. 2019;69:388-96.

84. Wirz Y, Meier MA, Bouadma L, Luyt CE, Wolff M, Chastre J, et al. Effect of procalcitonin-guided antibiotic treatment on clinical outcomes in intensive care unit patients with infection and sepsis patients: a patient-level meta-analysis of randomized trials. Crit Care. 2018;22:11. https://doi.org/10.1186/s13054-018-2125-7.

85. Havey TC, Fowler RA, Daneman N. Duration of antibiotic therapy for bacteremia: a systematic review and meta-analysis. Crit Care. 2011;15:R267. https://doi.org/10.1186/cc10545.

86. Hanretty AM, Gallagher JC. Shortened courses of antibiotics for bacterial infections: a systematic review of randomized controlled trials. Pharmacotherapy. 2018;38:674-87.

87. Timsit JF, Bassetti M, Cremer O, Daikos G, de Waele J, Kallil A, et al. Rationalizing antimicrobial therapy in the ICU: a narrative review. Intensive Care Med. 2019;45:172-89.

88. Chotiprasitsakul D, Han JH, Cosgrove SE, Harris AD, Lautenbach E, Conley AT, et al. Comparing the outcomes of adults with Enterobacteriaceae bacteremia receiving short-course versus prolonged-course antibiotic therapy in a multicenter, propensity score-matched cohort. Clin Infect Dis. 2018;66:172-7.

89. Montravers P, Tubach F, Lescot T, Veber B, Esposito-Farèse M, Seguin $\mathrm{P}$, et al. Short-course antibiotic therapy for critically ill patients treated for postoperative intra-abdominal infection: the DURAPOP randomised clinical trial. Intensive Care Med. 2018;44:300-10.

90. Pierrakos C, Velissaris D, Bisdorff M, Marshall JC, Vincent JL. Biomarkers of sepsis: time for a reappraisal. Crit Care. 2020;24: 287. https://doi.org/10.1186/s13054-020-02993-5.

91. Aksaray S, Alagoz P, Inan A, Cevan S, Ozgultekin A. Diagnostic value of sTREM-1 and procalcitonin levels in the early diagnosis of sepsis. North Clin Istanb. 2016;3:175-82.

92. Brenner T, Uhle F, Fleming T, Wieland M, Schmoch T, Schmitt F, et al. Soluble TREM-1 as a diagnostic and prognostic biomarker in patients with septic shock: an observational clinical study. Biomarkers. 2017;22:63-9.

93. Khater WS, Salah-Eldeen NN, Khater MS, Saleh AN. Role of suPAR and lactic acid in diagnosing sepsis and predicting mortality in elderly patients. Eur J Microbiol Immunol. 2016;6:178-85.

94. Yin WP, Li JB, Zheng XF, An L, Shao H, Li CS. Effect of neutrophil CD64 for diagnosing sepsis in emergency department. World J Emerg Med. 2020;11:79-86.

95. Kweon OJ, Choi JH, Park SK, Park AJ. Usefulness of presepsin (sCD14 subtype) measurements as a new marker for the diagnosis and prediction of disease severity of sepsis in the Korean population. J Crit Care. 2014;29:965-70.

96. Lu B, Zhang Y, Li C, Liu C, Yao Y, Su M, et al. The utility of presepsin in diagnosis and risk stratification for the emergency patients with sepsis. Am J Emerg Med. 2018;36:1341-5.

97. Hamed S, Behnes M, Pauly D, Lepiorz D, Barre M, Becher T, et al. Diagnostic value of Pentraxin-3 in patients with sepsis and septic shock in accordance with latest sepsis-3 definitions. BMC Infect Dis. 2017;17:554. https://doi.org/10.1186/s12879-0172606-3.
98. Larsson A, Tyden J, Johansson J, Lipcsey M, Bergquist M, Kultima $\mathrm{K}$, et al. Calprotectin is superior to procalcitonin as a sepsis marker and predictor of 30-day mortality in intensive care patients. Scand J Clin Lab Invest. 2020;80:156-61.

99. Song J, Park DW, Moon S, Cho HJ, Park JH, Seok H, et al. Diagnostic and prognostic value of interleukin-6, pentraxin 3, and procalcitonin levels among sepsis and septic shock patients: a prospective controlled study according to the Sepsis-3 definitions. BMC Infect Dis. 2019;19:968. https://doi.org/10.1186/ s12879-019-4618-7.

100. Grover V, Pantelidis P, Soni N, Takata M, Shah PL, Wells AU, et al. A biomarker panel (Bioscore) incorporating monocytic surface and soluble TREM-1 has high discriminative value for ventilator-associated pneumonia: a prospective observational study. PLoS One. 2014;9:e109686. https://doi.org/10.1371/ journal.pone.0109686.

101. Kim H, Hur M, Moon HW, Yun YM, Di Somma S, Network G. Multi-marker approach using procalcitonin, presepsin, galectin-3, and soluble suppression of tumorigenicity 2 for the prediction of mortality in sepsis. Ann Intensive Care. 2017;7:27.

102. Song Y, Chen Y, Dong X, Jiang X. Diagnostic value of neutrophil CD64 combined with CRP for neonatal sepsis: a meta-analysis. Am J Emerg Med. 2019;37:1571-6.

103. Dolin HH, Papadimos TJ, Stepkowski S, Chen X, Pan ZK. A novel combination of biomarkers to herald the onset of sepsis prior to the manifestation of symptoms. Shock. 2018;49:364-70. https://doi.org/10.1186/s13613-017-0252-y.

104. Mearelli F, Fiotti N, Giansante C, Casarsa C, Orso D, De Helmersen $\mathrm{M}$, et al. Derivation and validation of a biomarkerbased clinical algorithm to rule out sepsis from noninfectious systemic inflammatory response syndrome at emergency department admission: a multicenter prospective study. Crit Care Med. 2018;46:1421-9.

105. McHugh L, Seldon TA, Brandon RA, Kirk JT, Rapisarda A, Sutherland AJ, et al. A molecular host response assay to discriminate between sepsis and infection-negative systemic inflammation in critically ill patients: discovery and validation in independent cohorts. PLoS Med. 2015;12:e1001916. https://doi.org/10. 1371/journal.pmed.1001916.

106. Sweeney TE, Shidham A, Wong HR, Khatri P. A comprehensive time-course-based multicohort analysis of sepsis and sterile inflammation reveals a robust diagnostic gene set. Sci Transl Med. 2015;7:287ra71. https://doi.org/10.1126/scitranslmed.aaa5993.

107. Maslove DM, Shapira T, Tyryshkin K, Veldhoen RA, Marshall JC, Muscedere J. Validation of diagnostic gene sets to identify critically ill patients with sepsis. J Crit Care. 2019;49:92-8.

108. Schenz J, Weigand MA, Uhle F. Molecular and biomarker-based diagnostics in early sepsis: current challenges and future perspectives. Expert Rev Mol Diagn. 2019;19:1069-78.

109. Mauri T, Coppadoro A, Bombino M, Bellani G, Zambelli V, Fornari C, et al. Alveolar pentraxin 3 as an early marker of microbiologically confirmed pneumonia: a threshold-finding prospective observational study. Crit Care. 2014;18:10. https://doi.org/10. 1186/s13054-014-0562-5.

110. Olguner SK, Boyar B, Alabaz D, Erman T, Oktay K, Arslan A, et al. Tumor necrosis factor alpha and interleukin-1 beta levels in cerebrospinal fluid examination for the diagnosis of ventriculoperitoneal shunt-related ventriculitis. Childs Nerv Syst. 2019;35:629-36.

111. Sühs K-W, Novoselova N, Kuhn M, Seegers L, Kaever V, MüllerVahl K, et al. Kynurenine is a cerebrospinal fluid biomarker for bacterial and viral central nervous system infections. J Infect Dis. 2019;220:127-38.

112. El Feghaly RE, Stauber JL, Tarr PI, Haslam DB. Intestinal inflammatory biomarkers and outcome in pediatric Clostridium difficile infections. J Pediatr. 2013;163:1697-704. 
113. Crawford K, DeWitt A, Brierre S, Caffery T, Jagneaux T, Thomas $\mathrm{C}$, et al. Rapid biophysical analysis of host immune cell variations associated with sepsis. Am J Respir Crit Care Med. 2018;198: 280-2.

114. Kwon S, Kurmashev A, Lee MS, Kang JH. An inflammatory vascular endothelium-mimicking microfluidic device to enable leukocyte rolling and adhesion for rapid infection diagnosis. Biosens Bioelectron. 2020;168:112558. https://doi.org/10.1016/j. bios.2020.112558.

115. Fleuren LM, Klausch TLT, Zwager CL, Schoonmade LJ, Guo T, Roggeveen LF, et al. Machine learning for the prediction of sepsis: a systematic review and meta-analysis of diagnostic test accuracy. Intensive Care Med. 2020;46:383-400.

116. Taneja I, Reddy B, Damhorst G, Dave Zhao S, Hassan U, Price Z, et al. Combining biomarkers with EMR data to identify patients in different phases of sepsis. Sci Rep. 2017;7:10800. https://oi.org/ 10.1038/s41598-017-09766-1.

117•. Rawson TM, Hernandez B, Moore LSP, Blandy O, Herrero P, Gilchrist M, et al. Supervised machine learning for the prediction of infection on admission to hospital: a prospective observational cohort study. J Antimicrob Chemother. 2019;74:1108-15. Rawson et al. highlight the potential utility of machine learning by using commonly available laboratory values (C-reactive protein, white cell count, creatinine, alanine transaminase, bilirubina nd alkaline phosphatase to develop a prediction tool that approximates that of procalcitonin.

118. Hung SK, Lan HM, Han ST, Wu CC, Chen KF. Current evidence and limitation of biomarkers for detecting sepsis and systemic infection. Biomedicines. 2020;8. https://doi.org/10.3390/ biomedicines 8110494

119. Huang DT, Ramirez P. Biomarkers in the ICU: less is more?Yes. Intensive Care Med. 2020. https://doi.org/10.1007/s00134-02006271-4.

120. Vincent JL, Sakr Y, Sprung CL, Ranieri VM, Reinhart K, Gerlach $\mathrm{H}$, et al. Sepsis in European intensive care units: results of the SOAP study. Crit Care Med. 2006;34:344-53.

121. Blanco J, Muriel-Bombin A, Sagredo V, Taboada F, Gandia F, Tamayo L, et al. Incidence, organ dysfunction and mortality in severe sepsis: a Spanish multicentre study. Crit Care. 2008;12: R158. https://doi.org/10.1186/cc7157.

122. Martin CM, Priestap F, Fisher H, Fowler RA, Heyland DK, Keenan SP, et al. A prospective, observational registry of patients with severe sepsis: the Canadian Sepsis Treatment and Response Registry. Crit Care Med. 2009;37:81-8.

123. Gupta S, Sakhuja A, Kumar G, McGrath E, Nanchal RS, Kashani KB. Culture-negative severe sepsis: nationwide trends and outcomes. Chest. 2016;150:1251-9.

124•. Seymour CW, Kennedy JN, Wang S, Chang CH, Elliott CF, Xu $Z$, et al. Derivation, validation, and potential treatment implications of novel clinical phenotypes for sepsis. JAMA. 2019;321: 2003-17. Seymour et al. identify novel sepsis phenotypes supported by extensive biomarker analysis, demonstrating potential differences in response to infection between patients.

Publisher's Note Springer Nature remains neutral with regard to jurisdictional claims in published maps and institutional affiliations. 